\title{
What Does Wukan Have to Do With Democracy?
}

\section{Luigi Tomba}

In September 2011, the village of Wukan, Guangdong Province, made international headlines for its violent protests against the illegal sale of land by their corrupt village elite. Villagers were successful in both toppling the existing village leadership and electing, in their stead, the moral leaders of the revolt as their new village committee. A few months ago, the original leader of the protests was arrested on unclear corruption charges, an event that led to violent clashes between villagers and police. Is Wukan's sad story an example of a conscious democratic challenge to the existing system?
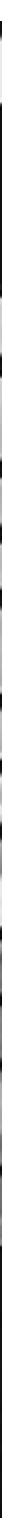
In September 2011, the village of $\mathrm{Wu}$ kan in Eastern Guangdong province became the centre of a media storm and made international headlines for its violent protests against the illegal sale of land by their established, and corrupt, village elite. Village leaders had taken it upon themselves to sell large chunks of village land without consulting the villagers, formally the collective owners of the land-use rights. Villagers in Wukan were successful in both toppling the existing village leadership and electing, in their stead, the moral leaders of the revolt as their new village committee. What was more important, in the tightly controlled Chinese system of village elections, was that villagers were allowed to cast a secret ballot.

Yet, despite international media calling Wukan the ultimate example of a democratic trend in rural China, the situation of the villagers changed little. The government claimed that part of the land-stealing controversy was resolved 'according to the law', which took some of the wind out of the sails of the collective protests. Ultimately, however, the land-use rights were not returned to their owners. The new leadership rapidly split and members of the newly elected village committee were then investigated for petty acts of corruption and were themselves forced to write 'confessions'. The original leader of the protests, Lin $\mathrm{Zu}$ luan, was re-elected in 2015 with ninety percent of the votes, only to be arrested on unclear corruption charges in mid2016. As it so often happens in these corruption cases, facts and circumstances are hard to ascertain. An Al Jazeera series of reports exposed the banality of village in-fighting between 2012 and 2015, along with the progressive re-assertion of state control over the conflict-ridden village. The arrest of Lin, seen by many as a moral beacon in this complex story, led to new violent clashes with the police, and to the almost inevitable analysis of the end of Wukan's 'democratic experiment'.
Is Wukan's sad story an example of a conscious democratic challenge to the existing system, as it has often been argued? Is every conflict in China that attracts the attention of the media a new step towards an inevitable democratic future? The battles in the streets, with national flag-bearing villagers throwing stones at riot police are generated much less by a desire to change the political system than they are by the exclusion of countless villagers from the spoils of economic growth and urbanisation. Villagers have seen the value of their land grow and the profits of urbanisation being appropriated by greedy local elites in the name of national development. Villagers' slogans are invariably about the redressing of a wrong, not a call for a rather distant idea of democracy. In a competition with the predatory urban governments, the cards are stacked against the village collectives, often leaving little alternative to violence. And these conflicts are everywhere, potentially much more significant for prosperity, stability, and justice in China than for its democratic future. Arguing that the story of Wukan is about China's transition into a liberal democracy would be forgetting the structural conditions that have led to this local conflict in the first place.

\section{Urbanisation and Land Ownership}

To explain some of these conditions, let's take a step back. One of the pillars of China's authoritarian system, and the main remnant of its socialist planned past, is the public ownership of land. In the cities, this takes the form of 'state ownership' while in the countryside the collectives (the villages) can claim the ownership of use rights over agricultural land. Villages are not formally considered to be a level of 'government', but are instead a level of 'self-administration'-a subtle but important distinction that 
contributes to explaining why villages committees are the only part of the governance structure where leaders can be elected, not appointed.

In this context, urbanisation inevitably necessitates the 'conversion' of collectively owned land into state-owned land. Urban administrations reap significant advantages from conversion, as the price of expropriation or acquisition of rural land is invariably a small fraction of the price that they can obtain when they lease the land on the market. The competition is very intense and a matter of survival for both villagers and urban governments. Various estimates suggest that, on average, villagers end up being significantly short-changed. According to a report by Jiang Ming at Peking University, the market price of expropriated land is, on average, more than fourteen times higher than the cost of compensation. There are, of course, substantial variations, and some strategically located peri-urban villages have successfully negotiated handsome compensation packages through unified and collective bargaining, especially when, because of rapid urbanisation, some of these 'urban villages' have ended up owning land in central areas of Guangzhou or Shenzhen. Yet, in general, these remain the exception rather than the rule, and local governments use violence and even local thugs to evict village residents.

City governments can be only partly blamed for having such an aggressive stance. This is because growth in their territory, their capacity to provide services to an increasing population, and their implementation of higher-level government policies remain highly dependent on land. Because of the centralised taxation system, land fees are among the few components of an urban government's revenue that stay local. This has turned cities into aggressive agents of expropriation as, according to the law, rural land can only be turned into 'construction land' once it has been converted to state-owned land and their inhabitants relocated or given an urban household registration (hukou). Despite central attempts to limit expropriation in the name of the preservation of the already limited amount of arable land in the country, the dependence of local governments on land sales has continued to grow over the last decade. On average, more than one quarter of urban governments' budget depends on land fees, and in some cities it is as high as forty or fifty percent. In 2012 alone, income from land fees grew nationwide by more the forty-six percent.

\section{The Plight of Chinese Villagers}

Villagers, for their part, have experienced expropriation since the 1980s. In the early period, it was easier for them to justify the state's intervention with the needs of economic development. Yet, after three decades of successive expropriations, the cases of neighbouring villages and the declining attraction of urban welfare (an urban registration was often offered in exchange for land-use rights) have made it more difficult and expensive to convince farmers to give up their land. With a much greater flow of information, they now know how much governments speculate on the land that is taken away from them, and they are no longer ready to sacrifice their interests in the name of national development.

Many 'rural' villages on the outskirts of large cities are also no longer relying on agriculture. Despite the legal limitations, they have often built significant collective industrial economies on their land and are now living from rent paid by factories, as well as the income generated by a growing army of migrant workers who need accommodation, food, and services. They no longer see their land as a munificent concession of the socialist state but as a long-held entitlement, and have created complex local institutions to control 
their collective economies. Shareholding cooperatives have been set up, for example, that spread from Guangdong to many other parts of the country, turning villagers into shareholders of their village corporation. Shares (that cannot be sold outside of the collective) have now replaced land, and traditional village elites have consolidated their capacity to decide on important aspects of the village economy with limited consultation with the villagers.

These are concerns that Wukan's villagers are familiar with and clearly not only theirs. About two-thirds of the estimated 187,000 collective conflicts a year across the country have something to do with land. Last year, land also replaced corruption as the main area of dissatisfaction in the government's work among Chinese citizens, probably suggesting that, while the centrally engineered anti-corruption campaign is generating positive vibes, the aggressive stance of local urban governments (and the growing prices of real estate) is increasingly becoming a focal point in China's public opinion.

\section{Wukan as Symptom of a Rural Malaise}

When we think of Wukan in these terms, the democratic content of the violent resistance to the government's attempt to re-establish control over the village is hardly an indication of a growing democratic awareness, or a strong opposition to the existing institutions. Rather, the grievances stemming from the longterm infringement of local interests and the perception of being cheated by the local government contribute decisively to strengthening the resolve of these villagers. Yet, they hardly see the change of the current institutional arrangements as a solution to their grief. Much of the contestation has to do with the corruption of some officials. The election of their own leaders was supposed to return the land that was originally sold without their consent. The autonomy and special rules in the Wukan elections are part of the concessions resulting from the bargaining process in which local governments invariably engage when conflicts arise. By keeping that autonomy localthe result of specific negotiations, not a rule change-they very efficiently deny the possibility that a more democratic arrangement can emerge, that the legitimacy of higher-level leadership is affected, and that, eventually, the Wukan experience is systematically replicated.

This incident, and the massive contestation in the village between 2012 and 2016 is a very visible sign of China's rural malaise. Urbanising China is a massive attempt to nationalise its territory, to absorb collective economies that have in the last two decades been at the centre of China's industrialisation. It is driven by the structural needs of urban governments and observed with continuous apprehension by central authorities, always ready to tailor their intervention to the different realities of urbanisation in the country, to quell conflicts when they risk spilling beyond their local dimension. To look at Wukan as an experiment in local democracy would be too generous an evaluation for the current authoritarian government.

\section{Luigi Tomba}

Luigi Tomba is Associate Director of the Australian Centre on China in the World, The Australian National University. While his early research focused on China's labour reform, Luigi's best-known work is on urbanisation, the social engineering of a Chinese urban middle class, housing and land reform. His current research interests are informed by China's urban question, the ideological implications of China's project to urbanise the country, and its social, political, and territorial consequences. 